\title{
Talking about a re-evolution: blind alleys in ostracod phylogeny
}

\author{
DAVID J. HORNE \\ Department of Geography, Queen Mary University of London, Mile End Road, London E1 4NS, UK and Department of Zoology, The \\ Natural History Museum, Cromwell Road, London SW7 5BD, UK \\ (e-mail: d.j.horne@qmul.ac.uk)
}

\begin{abstract}
The description of a new genus of bairdiid ostracod, on the basis of possession of eye tubercles (previously unknown in the group), has been criticized on the grounds that such ocular structures are not a valid criterion for establishing a genus, and for the authors' failure to discuss adequately the phylogenetic implications of a sighted taxon apparently arising from blind ancestors. The latter point particularly refers to Dollo's Law, according to which complex evolutionary traits, once lost, cannot be regained. In response to these criticisms, criteria for sightedness in ostracods are reconsidered, leading to the conclusion that ostracods without eye tubercles are not necessarily blind. A brief review of recent literature (covering vertebrates, invertebrates and plants) demonstrates that Dollo's Law is not inviolable; on the contrary, there appear to be several well-documented examples of the reactivation of dormant genes, allowing the reappearance of 'lost' characters, in some cases after several million years. The implications for the occurrence of rare males in ancient asexual lineages are considered, and it is concluded that the loss of traits such as sightedness and sexual reproduction might not be irreversible. J. Micropalaeontol. 29(1): 81-85, May 2010.
\end{abstract}

KEYWORDS: Ostracoda, evolution, eyes, ancient asexuals, dormant genes

\section{INTRODUCTION: DOLLO'S LAW AND OSTRACOD EVOLUTION}

Darwinian evolution by natural selection, although it proceeds in simple steps, results in complex historical pathways leading to the development of species. It has been widely held that, given the long and winding nature of these evolutionary trails, combined with the constraints of contingency and ancestry, it is highly improbable that the same path could be traced more than once (see e.g., Gould, 1990). A complex character or trait, once lost from a lineage, is unlikely to re-evolve, since this would require the retracing of innumerable evolutionary steps in the right order and subject to the vagaries of changing selection pressures. The concept that once complex ancestral states are lost they cannot be regained is known as Dollo's Law, after the Belgian palaeontologist Louis Dollo (1857-1931) who first expressed it (Gould, 1970; Pagel, 2004). In genetic terms it implies that information is degraded 'sufficiently fast that genes or developmental pathways released from selective pressure will rapidly become nonfunctional' (Marshall et al., 1994: 12283). For example, sighted species of a marine benthonic ostracod genus living in the photic zone might evolve into deep ocean habitats and become blind, since having no use for eyes below the photic zone they would eventually lose them. If the ancestral shallow-water stock then became extinct, sight would be lost to the entire clade. Under such circumstances, if a surviving member of that clade should subsequently re-enter and re-adapt to life in the photic zone, it is generally considered highly unlikely that it could evolve sight a second time (at least, not by the same trajectory and with the same traits; the same function can evolve more than once, but the components and processes involved would most likely be different). The loss of sight would be, quite literally, an evolutionary blind alley.

Just such a scenario was encountered, however, by Dingle $(2003 \mathrm{a}, \mathrm{b})$ in his investigations of the marine ostracod fauna around Marion Island in the Southern Ocean, where he found sighted species of two predominantly blind, deep-sea genera: Dutoitella lesleyae Dingle, 2003a and Poseidonamicus whatleyi Dingle, 2003a. With due consideration of biogeography, ecology, dispersal mechanisms and phylogeny, he concluded that the sighted species could not have dispersed to the island from other shallow-water habitats but must, therefore, have evolved from blind, deep-water ancestors, and proposed the reactivation of dormant genes for sightedness as the most likely explanation for this apparent disregard for Dollo's Law (Dingle, 2003b). A detailed and thorough phylogenetic analysis of Poseidonamicus by Hunt (2007) subsequently raised objections to Dingle's hypothesis. One deep-sea species apparently has eye-tubercles yet is nested within a clade of other, blind deep-sea species, implying that it did not evolve from a shallow-water, sighted ancestor. Invoking Dollo's Law, Hunt (2007) considered and rejected the possibility that a progenitor of this species had migrated to shallower water, re-evolved eyes and then migrated back to deeper water to give rise to the sighted species. His favoured solution was to remove the conundrum altogether, by arguing that the supposed eye tubercles were in fact other ornamental features and not related to sight at all. Then, while admitting that Dollo's Law 'may not be as inviolable as once thought' (Hunt, 2007: 626), he concluded that sightedness in Dingle's species of Poseidonamicus was more likely to be primitive than secondarily acquired; this would mean that it must have evolved from a yet-to-be-discovered, sighted ancestor.

More recently van Itterbeeck et al. (2007) described a new, Palaeogene ostracod genus of the family Bairdiidae on the basis of its possession of eye tubercles, a feature not seen in any other bairdiids throughout their long (Ordovician-Recent) fossil record. Dingle (2009) takes issue with Oculobairdoppilata van Itterbeeck et al., 2007, firstly because he does not consider the presence or absence of eye tubercles to be a valid character state for taxonomic distinction at generic level and, secondly, because the authors of the genus failed to discuss adequately the 
phylogenetic implications of their taxonomic decision, specifically that the evolution of a sighted species from what Dingle (2009) considers to be blind ancestors is in direct contravention of Dollo's Law. In response to these criticisms there are three issues to be addressed: whether or not eye tubercles are a valid diagnostic character at generic level, the reliability of valve morphology as an indicator of sightedness, and the consequences of implying that a lost, complex trait was regained, against Dollo's Law.

\section{IS THE PRESENCE/ABSENCE OF EYE TUBERCLES SIGNIFICANT AT GENERIC LEVEL?}

Dingle (2009) argues that establishing a new genus on the basis of its possession of eye tubercles perpetuates a taxonomic inconsistency; he once considered eye tubercles to be of at least subgeneric significance himself, but he now thinks otherwise and claims the support of the 'broad church of fossil ostracod workers' (Dingle, 2009: 88) for this view. As a dissenter, who would rather base taxonomic decisions on the available data than on the hypothetical consequences of an evolutionary concept, I disagree. Some workers may have their cake, others may eat it; it is satisfying and encouraging when we do arrive at a consensus view, but there is no law that says we must. There is ample scientific justification for describing a new genus on the basis of a distinctive morphological feature possessed by one and probably more species. The practical taxonomic implications are hardly tortuous and if other workers consider the character to be inadequate justification for generic distinction, then they are at liberty to retain the original generic name for those species.

Taxonomic arguments notwithstanding, assignments above the species level hold limited significance for phylogenetic interpretations. Dingle (2009) cites the example of 'blind' Albian species of Hemingwayella Neale, 1975 (other species of which have eye tubercles) for which he once established the new subgenus Parahemingwayella Dingle, 1984; he now accepts the subsequent decision of Ayress et al. (1995) that the presence/ absence of eye tubercles is not of generic/subgeneric significance. Recognizing the necessity for 'blind' Hemingwayella to have a sighted ancestor is logical but this is not, as Dingle (2009) argues, a consequence of the taxonomic placement of the species in one genus, which includes blind and sighted species, rather than in another, blind subgenus.

The same logic applies, regardless of the genus or genera to which the species are assigned. A distinction might be made between the acquisition of a character and its loss; the former could be regarded as taxonomically very significant, the latter less so because it can happen repeatedly and more easily. To apply this distinction requires a phylogenetic concept of a genus rather than just a morphological one (see e.g., Martens, 2007). The genus, and all other taxonomic levels above the species, are artificial constructs that allow us to group taxa according to perceived similarities and separate them according to perceived differences (the morphological concept); such groupings may indicate common ancestry but, alternatively, may be due to homoeomorphy in groups which are only distantly related. Regardless of whether you call them Bairdoppilata or Oculobairdoppilata there will still be a group of bairdiids with eye tubercles. To separate such a group from the original genus and unite them under a new generic name, taking into consideration not only common morphology but also stratigraphical and geographical proximity, is to propose the hypothesis that they are a natural clade with common ancestry (the phylogenetic concept). This hypothesis is testable by means of cladistic analysis based on shared character states at the species level, to which generic assignments are largely irrelevant. Establishing a separate supra-specific taxon for a group of species apparently united by a distinctive acquired character or set of characters is potentially useful in drawing attention to such a group, in which common morphology may reflect common ancestry (loss of characters, on the other hand, is a poor guide to ancestry). A consequent challenge to phylogenetic interpretations should not be regarded as heresy, but as a significant issue to be addressed and, if possible, resolved; I agree with Dingle that these issues should not be ignored.

\section{EYE TUBERCLES AND SIGHTEDNESS}

Sighted ostracods often have ocular structures in their valves: externally visible eye spots or tubercles and/or internal ocular sinuses. However, the presence/absence of such structures cannot be considered a reliable criterion on which to judge whether or not an ostracod is/was sighted. van Itterbeeck et al. (2007) cited the example of living Neonesidea oligodentata (Kajiyama, 1913), a bairdiid ostracod which is sighted but has no indication of this in the valve morphology. Müller (1894) described and illustrated several sighted bairdiids. Tanaka (2005) identified bairdiids as having 'Type 1' eyes, with the naupliar eye separated from the carapace; citing Claus (1891) he noted that bairdiid valves, which are typically pigmented or opaque, have clear areas near the eye. It seems probable that many shallow-water bairdiids are not blind, but have functional eyes; in the absence of calcareous ocular structures such as tubercles, however, only specimens collected alive can provide evidence of sightedness. Another example is provided by the Order Platycopida, members of which were considered for a long time and by general consensus to be blind (see e.g., Hartmann \& Guillaume, 1996); this turns out not to be the case for living Keijcyoidea infralittoralis Tsukagoshi, Okada \& Horne, 2006 and Cytherella sordida G. W. Müller, 1894, both of which possess a median nauplius eye (Müller, 1894; Tsukagoshi et al., 2006; Okada et al., 2008). In K. infralittoralis, eyes have been observed in both sexes and in juveniles, but there are no ocular structures in the valves and it seems quite possible that many platycopids are and have been sighted (the broad church of ostracodologists is not always right!) although their fossil record offers little evidence of this (an exception may be a Carboniferous platycopid illustrated by Lundin (1987) in which apparent eye spots are at least externally visible). According to Tanaka (2005, 2006), other ostracod taxa known to have eyes but not ocular structures include members of the Bythocytheridae, Candonidae and Darwinulidae, while species of the Paradoxostomatidae have very thin cuticular lenses in their thin, transparent valves which show little sign of anything that could be called an eye tubercle (see, e.g., Horne \& Whittaker, 1985). Tanaka's (2005, 2006) study dealt mainly with marine ostracods and did not take account of the non-marine Cyprididae, another diverse group which are mostly sighted but lack ocular structures in their valves. 
If a fossil ostracod has eye spots, eye tubercles or internal ocular sinuses in its valves, it is reasonable to assume that it was sighted (notwithstanding the possibility that a species might subsequently have become blind but retained its eye tubercles because they had acquired an additional function, not related to sight, such as morphological mate recognition). If a fossil ostracod lacks ocular structures in the valves, however, it is not equally reasonable to assume that it was blind. Thus we have no evidence that bairdiids in general have always been blind, but we do have evidence that at least some living ones are sighted; it is parsimonious to consider that the lineage has always included sighted taxa. The evolution of Oculobairdoppilata is not an example of gene reactivation, and the description of the new genus does not create a phylogenetic anomaly. The most likely scenario, based on available data, is that its immediate ancestor was a sighted species of Bairdoppilata without ocular structures in the valves. In this particular case the development of eye tubercles represents an advantageous improvement of an existing feature, sight, by the evolutionary innovation of ocular structures in the calcareous valves; it does not represent the re-evolution of something that was previously lost. There is no case to answer in Dollo's court.

Dingle's (2009) other example, the evolution of Oculocytheropteron Bate, 1972 (Late Cretaceous-Recent) from Cytheropteron Sars, 1866 (Early Jurassic-Recent) may pose a real challenge to Dollo's Law. Bate (1972) described the new genus Oculocytheropteron for species of Cytheropterinae with, among other diagnostic features, a well-developed eye tubercle situated just below the anterior cardinal angle. On the basis of several published species (formerly assigned to Cytheropteron) as well as the type species, O. praenuntatum Bate, 1972, he determined its stratigraphical range as Late Cretaceous (Santonian) to Recent and suggested that it was restricted to the Southern Hemisphere. The inclusion of a single Northern Hemisphere species, the Pleistocene to Recent Cytheropteron nodosum Brady, 1868 , was tentatively suggested by Bate but later rejected by Whatley \& Masson (1980) who pointed out that in this case the feature interpreted as an eye tubercle lacks an internal ocular sinus and is, in fact, part of the external surface ornament. Bate's (1972) description and illustrations make it clear that, in addition to the externally expressed eye tubercle, the internal ocular pit of $O$. praenuntatum contains a convex lens surface, indicating that it has a biconvex lens similar to that of Oculobairdoppilata. Dingle's (2009) contention that the genus Cytheropteron is functionally blind because it lacks ocular structures in the valves is simply wrong. It appears to be correct, however, to say that the genus is blind because it has no median naupliar eye (Sars, 1926; Van Morkhoven, 1963). The Family Cytheruridae, to which Cytheropterinae such as Cytheropteron and Oculocytheropteron belong, includes other blind (e.g. Kangarina Coryell \& Fields, 1937) and sighted (e.g. Semicytherura Wagner, 1957; Hemicytherura Elofson, 1941) genera. The possibility that species of Cytheropteron were also sighted but lacked eye tubercles, at least until the Late Cretaceous, cannot be ruled out entirely, although it is more parsimonious to assume that this was not the case. It is therefore reasonable to advance the hypothesis that, having arisen from a sighted common ancestor, some cytherurid lineages lost their eyes and, in the case of Oculocytheropteron at least, subsequently regained them. This hypothesis, which could be falsified by the discovery of either a living, sighted species of Cytheropteron or a species of Oculocytheropteron at least as old as the Early Jurassic, does imply that Dollo's Law has been infringed. Is this really so unlikely that other explanations should be sought? Is Dollo's Law unbreakable, or could a sightless ostracod lineage find its way out of the blind alley by re-evolving eyes?

\section{NOT A LAW AS SUCH, MORE OF A GUIDELINE}

The assumption that complex traits, once lost, are unlikely to be regained is undoubtedly deeply-rooted in many areas of evolutionary biology and palaeontology (but note that it is often expressed in terms of probabilities rather than absolutes). The recent literature, however, positively sparkles with the shattered fragments of Dollo's Law. A critical review by Marshall et al. (1994) dismissed some claims for long-term (>10 million years) evolutionary reversals, such as the re-appearance of ancestral teeth in birds, but found that potential for short-term ( $<1$ million years) reactivation of morphogenetic processes does exist, for example in axolotls (neotenic larval salamanders), in which metamorphosis to the ancestral adult state can be induced by administering the hormone thyroxine. Such short-term switching on and off during the diversification of a group could produce repeated losses and recoveries, maintaining partially hidden traits over much longer time-scales and producing many homoplasies in cladograms. Using molecular phylogenies, evidence has been presented that the evolutionary loss of fingers and toes in lizards is reversible (Kohlsdorf \& Wagner, 2006). Cypriniform fish lost their oral teeth (while retaining pharyngeal teeth) at least 50 million years ago, probably through adaptation to suction feeding. Although this loss has not been reversed in subsequent adaptive radiation, at least one group (zebrafish) apparently still retains some genetic capacity to re-evolve the development of oral teeth in the oral jaws, should selection for their function be re-introduced, but the realization of such a process may be inhibited by the loss or modification of other developmental genes (Jackman \& Stock, 2006). In stick insects, wings have evolved several times from wingless ancestors; rather than being dormant, ancestral 'wing genes' may have been kept in wingless forms because they performed other developmental functions (Whiting et al., 2003; Trueman et al., 2004; Whiting \& Whiting, 2004). Porter \& Crandall (2003), in a review of evidence for evolutionary reversals through loss or simplification (in which Dollo is never mentioned), considered several examples of phenotypic (morphological, physiological or behavioural) regression to ancestral states. They highlighted the case of a fish species which exists in both eyeless, cave dwelling and sighted, surface-dwelling populations; blind forms may retain the potential to develop eyes, at least at the embryonic level. Coiling in gastropod shells is an ancestral state, secondarily lost in some lineages such as limpets; the phylogeny of slipper limpets, however, suggests that coiled taxa evolved from uncoiled ancestors after the trait had remained hidden for between 20 and 100 million years (Collin \& Cipriani, 2003; Pagel, 2004). In at least some species coiling is retained in larvae although absent in adults; in such a case, heterochronic evolution can result in the re-appearance of coiled adults. Lönnig et al. (2007) discussed the apparent re-appearance of features such as leaf-like sepals, a plesiomorphic state, in an angiosperm 
lineage and concluded that Dollo's Law can be broken, at least at the phenotypic level.

In a modern anostracan branchiopod species the substitution of a single, median eye for the paired eyes normally found in the group represents an ancient atavism, challenging the notion that reactivation of silent genes is impossible after $>10$ million years (Fryer, 1999). Parasitism is widely regarded as an evolutionary dead end, since it results in the simplification by reduction of an organism which loses its adaptations for a free-living life; Cruickshank \& Paterson (2006) challenged this paradigm of irreversibility, citing examples from mites and nematodes to show that returns to non-parasitic states are not as rare as previously thought.

Perhaps the most intriguing example occurs in one of several clades of oribatid mites that, like bdelloid rotifers and darwinulid ostracods, are regarded as 'ancient asexuals'. One sexual family of oribatids, the Crotoniidae, is now hypothesized to have evolved from within an asexual clade, potentially adding the re-evolution of sexuality to the list of contradictions of Dollo's Law (Domes et al., 2007). Asexual mites occasionally produce rare, non-functional males; Domes et al. (2007) suggest that the cost of such rare events is negligible and may provide a mechanism to maintain ancestral genes for sexuality within a lineage over long time-scales (although if male function predominantly involves genes which function exclusively in males then re-evolution of sex is less likely than for other traits). Rare males have also been recorded in presumed parthenogenetic populations of certain ostracod species. In the case of Limnocythere inopinata Baird, 1843, the occurrence of a few atavistic males among thousands of females from a central European lake (Geiger et al., 1998; Yin et al., 1999) can only be taken as evidence of reversion on a short time-scale, since fully sexual populations are known to live today in other parts of the world including eastern Europe, and fossil sexual populations existed in Europe as recently as the last interglacial $(<0.2$ million years ago) and possibly the Late glacial-early Holocene $(<0.02$ million years ago) (Martens, 1998; Schön \& Martens, 1998; Horne \& Martens, 1999). The recent discovery of rare males of the darwinulid Vestalenula cornelia Smith, Kamiya \& Horne, 2006 poses a far greater problem since it has been argued that males were unknown in this lineage for as long as 250 million years (Martens et al., 2003; Smith et al., 2006). It remains to be determined whether these are indeed long time-scale atavisms or evidence that some darwinulids, at least, are sexual. These enigmatic examples suggest that the possibility of evolutionary reversals in ancient asexual lineages may merit greater attention than it has hitherto received.

\section{CONCLUSION}

The 'inescapable conclusion' (Dingle, 2009: 88) that taxa with eye tubercles cannot have evolved from ancestors that lacked them stumbles on the mistaken belief that Dollo's Law is unbreachable and falls on the false premise that the absence of eye tubercles always signifies blindness. The argument about whether or not the presence of ocular structures is a valid generic character is largely irrelevant to issues of phylogeny. Nevertheless, the question of whether or not re-evolution has occurred in ostracod phylogeny is a fascinating and pertinent one, worthy of more detailed investigation. Given the rather substantial evi- dence that re-evolution has occurred in other organisms, serious consideration should surely be given to the possibility that is has also occurred in ostracod lineages. The loss of traits such as sightedness and sexual reproduction may not lead to evolutionary dead ends after all, but could be reversible.

\section{ACKNOWLEGEMENTS}

The author is grateful to Richard Dingle for discussing his views on ostracod eyes and Dollo's Law during a chance meeting in the Heron-Allen Library at the Natural History Museum in London; subsequently he kindly provided a pre-publication copy of his 'Further visions ...' essay which allowed preparation of this response. Alan Lord is thanked for valuable advice and comment in the early stages of writing this essay, as are Roger Butlin and Koen Martens, whose critical reading of a late draft helped make substantial improvements.

\section{Manuscript received 5 October 2009 Manuscript accepted 25 January 2010}

\section{References}

Ayress, M.A., Whatley, R.C., Downing, S.E. \& Millson, K.J. 1995. Cainozoic and Recent deep sea cytherurid Ostracoda from the South Western Pacific and Eastern Indian oceans, Part I: Cytherurinae. Records of the Australian Museum, 47: 203-223.

Bate, R.H. 1972. Upper Cretaceous Ostracoda from the Carnarvon Basin, Western Australia. Special Papers in Palaeontology, 10, 85pp.

Claus, C. 1891. Das Medianauge der Crustaceen. Arbeiten aus dem Zoological Institute, Wien, 9: 225-266.

Collin, R. \& Cipriani, R. 2003. Dollo's law and the re-evolution of shell-coiling. Proceedings of the Royal Society of London, B, 270: 2551-2555.

Cruickshank, R.H. \& Paterson, A.M. 2006. The great escape: do parasites break Dollo's law? TRENDS in Parasitology, 22: 509-515.

Dingle, R.V. 1984. Mid-Cretaceous Ostracoda from southern Africa and the Falkland Plateau. Annals of the South African Museum, 93(3): 97-211.

Dingle, R.V. 2003a. Recent subantarctic benthic ostracod faunas from the Marion and Prince Edward Islands archipelago, Southern Ocean. Revista Española de Micropaleontología, 35(1): 119-155.

Dingle, R.V. 2003b. Some palaeontological implications of putative, longterm, gene reactivation. Journal of the Geological Society, London, 160: $815-818$.

Dingle, R.V. 2009. Further visions of Dollo's Law through ostracods' eyes: an essay. Journal of Micropalaeontology, 28: 87-89.

Domes, K., Norton, R.A., Maraun, M. \& Scheu, S. 2007. Reevolution of sexuality breaks Dollo's law. Proceedings of the National Academy of Sciences, 104: 7139-7144.

Fryer, G. 1999. The case of the one-eyed brine shrimp: are ancient atavisms possible? Journal of Natural History, 33: 791-798.

Geiger, W., Otero, M. \& Rossi, V. 1998. Clonal ecological diversity. In: Martens, K. (Ed.), Sex and Parthenogenesis - evolutionary ecology of reproductive modes in non-marine ostracods. Backhuys Publishers, Leiden, 243-256.

Gould, S.J. 1970. Dollo's Law: irreversibility and the status of evolutionary laws. Journal of the History of Biology, 3: 189-212.

Gould, S.J. 1990. Wonderful life: the Burgess Shale and the nature of history. Hutchinson Radius, London, 347pp.

Hartmann, G. \& Guillaume, M.C. 1996. Classe des Ostracodes (Ostracoda Latreille, 1802). In: Grassé, P.P. (Ed.), Traité de Zoologie, Tome VII, Crustacés, 2, Généralités et Systématique. Masson, Paris, 755839.

Horne, D.J. \& Martens, K. 1999. Geographical parthenogenesis in European non-marine ostracods: post-glacial invasion or Holocene stability? Hydrobiologia, 391: 1-7. 
Horne, D.J. \& Whittaker, J.E. 1985. A revision of the genus Paradoxostoma Fischer (Crustacea; Ostracoda) in British waters. Zoological Journal of the Linnean Society, 85: 131-203.

Hunt, G. 2007. Morphology, ontogeny and phylogenetics of the genus Poseidonamicus (Ostracoda: Thaerocytherinae). Journal of Paleontology, 81: 607-631.

Jackman, W.R. \& Stock, D.W. 2006. Transgenic analysis of Dlx regulation in fish tooth development reveals evolutionary retention of enhancer function despite organ loss. Proceedings of the National Academy of Sciences, 103: 19390-19395.

Kohlsdorf, T. \& Wagner, G.P. 2006. Evidence for the reversibility of digit loss: a phylogenetic study of limb evolution in Bachia (Gymnophthalmidae: Squamata). Evolution, 60: 1896-1912.

Lönnig, W.E., Stüber, K., Saedler, H. \& Kim, J.H. 2007. Biodiversity and Dollo's law: to what extent can the phenotypic differences between Pisopates orontium and Antirrhinum majus be bridged by mutagenesis? Bioremediation, Biodiversity and Bioavailability, 1(1): $1-30$.

Lundin, R.F. 1987. On Glyptolichvinella spiralis (Jones \& Kirkby). A Stereo-Atlas of Ostracod Shells, 14(32): 139-142.

Marshall, C.R., Raff, E.C. \& Raff, R.A. 1994. Dollo's law and the death and resurrection of genes. Proceedings of the National Academy of Sciences of the USA, 91: 12283-12287.

Martens, K. 1998. Sex and ostracods: a new synthesis. In: Martens, K. (Ed.), Sex and Parthenogenesis - evolutionary ecology of reproductive modes in non-marine ostracods. Backhuys Publishers, Leiden, 295-321.

Martens, K. 2007. On a new species and genus in the Cypridini (Crustacea, Ostracoda, Cyprididae) from South Africa, with a phylogenetic analysis of the tribe and a discussion on the genus concept in this group. Journal of Natural History, 41: 381-399.

Martens, K., Rossetti, G. \& Horne, D.J. 2003. How ancient are ancient asexuals? Proceedings of the Royal Society of London, series B (Biological Sciences), 270: 723-729.

Müller, G.W. 1894. Die Ostracoden des Golfes von Neapel und der angrenzenden Meeresabschnitte. Fauna und Flora des Golfes von Neapel, Monograph 21, Berlin, 404pp.

Okada, R., Tsukagoshi, A., Smith, R.J. \& Horne, D.J. 2008. The ontogeny of the platycopid Keijcyoidea infralittoralis (Ostracoda: Podocopa). Zoological Journal of the Linnean Society, 153: 213-237.

Pagel, M. 2004. Limpets break Dollo's Law. TRENDS in Ecology \& Evolution, 19: 278-280.
Porter, M.L. \& Crandall, K.A. 2003. Lost along the way: the significance of evolution in reverse. TRENDS in Ecology and Evolution, 18: $541-547$.

Sars, G.O. 1926. An account of the Crustacea of Norway. Volume $9-$ Ostracoda. Parts 13, 14 Cytheridae (continued). Bergen Museum, Bergen, Norway, pp. 209-240.

Schön, I. \& Martens, K. 1998. Sex determination in non-marine ostracods. In: Martens, K. (Ed.), Sex and Parthenogenesis - evolutionary ecology of reproductive modes in non-marine ostracods. Backhuys Publishers, Leiden, 25-36.

Smith, R.J., Kamiya, T. \& Horne, D.J. 2006. Living males of the 'ancient asexual' Darwinulidae (Ostracoda: Crustacea). Proceedings of the Royal Society of London, series B (Biological Sciences), 273: $1569-1578$

Tanaka, G. 2005. Morphological design and fossil record of the podocopid ostracod naupliar eye. Hydrobiologia, 538: 231-242.

Tanaka, G. 2006. Functional morphology and light-gathering ability of podocopid eyes and the palaeontological implications. Zoological Journal of the Linnean Society, 147: 97-108.

Trueman, J.W.H., Pfeil, B.E., Kelchner, S.A. \& Yeates, D.K. 2004. Did stick insects really regain their wings? Systematic Entomology, 29: $138-139$.

Tsukagoshi, A., Okada, R. \& Horne, D.J. 2006. Appendage homologies and the first record of eyes in platycopid ostracods, with the description of a new species of Keijcyoidea (Crustacea: Ostracoda) from Japan. Hydrobiologia, 559: 255-274.

van Itterbeeck, J., Morsi, A-M.M., Horne, D.J. \& Speijer, R.P. 2007. Oculobairdoppilata gen. nov. (Ostracoda, Bairdiidae): a new genus from the Paleocene of Tunisia. Journal of Micropalaeontology, 26: 97-101.

Van Morkhoven, F.P.C.M. 1963. Post-Palaeozoic Ostracoda. Their morphology, taxonomy and economic use. Vol. II, generic descriptions. Elsevier, Amsterdam, 478pp.

Whatley, R.C. \& Masson, D. 1980. The ostracod genus Cytheropteron from the Quaternary and Recent of Great Britain. Revista española Micropaleontologia, 11: 223-277.

Whiting, M.F. \& Whiting, A.S. 2004. Is wing recurrence really impossible?: a reply to Trueman et al. Systematic Entomology, 29: 140-141.

Whiting, M.F., Bradler, S. \& Maxwell, T. 2003. Loss and recovery of wings in stick insects. Nature, 421: 264-267.

Yin, Y., Geiger, W. \& Martens, K. 1999. Effects of genotype and environment on phenotypic variability in Limnocythere inopinata (Crustacea, Ostracoda). Hydrobiologia, 400: 85-114. 